\title{
Factors Affecting Saving and Investment Behavior of the Teachers
}

\author{
Kumari Asmita ${ }^{1}$, Satya Prakash ${ }^{2 *}$ and Kritika ${ }^{3}$ \\ ${ }^{1}$ College of Home Science, Department of Family Resource management, Dr. R.P.C.A.U., \\ Pusa, Samastipur, Bihar-848125, India \\ ${ }^{2}$ Department of Extension Education Dr. R.P.C.A.U., Pusa, Samastipur, Bihar-848125, India \\ ${ }^{3}$ College of Home Science, Department of Home Science Extension and Communication \\ Management, Dr. R.P.C.A.U., Pusa, Samastipur, Bihar-848125, India \\ *Corresponding author
}

\section{A B S T R A C T}

\begin{tabular}{|l|}
\hline Ke y w o r d s \\
Savings, \\
Investments, \\
Factors affecting \\
\hline Article Info \\
\hline $\begin{array}{l}\text { Accepted: } \\
\text { 02 May } 2018 \\
\text { Available Online: } \\
\text { 10 June 2018 }\end{array}$ \\
\hline
\end{tabular}

Saving and investment behaviour is influenced by several factors are Income, Education, Wealth, Employment Status, Stages in life cycle, Pension, Insurance and Banking infrastructure (Achar, 2012). It is supported that the $85 \%$ of the high school teachers and $80 \%$ of college teachers were highly influenced by income as saving and high school teachers were influenced as education $(77.5 \%)$, wealth $(47.5 \%)$, pension $(32.5 \%)$, stages in life cycle $(30 \%)$, banking infrastructure $(25 \%)$ and employment status $(10 \%)$ respectively whereas college teachers were influenced as education $(77.5 \%)$, stages in life cycle $(37.5 \%)$, wealth and pension (35\%), banking infrastructure $(27.5 \%)$ and employment status (20\%) respectively. Tabassum Sultana and Pardhasaradhi (2012) carried out a survey on factors influencing Indian individual equity investors' decision-making and behaviour. It is supported that the high school respondents $(82.5 \%)$, decision of investment was influenced by the factor 'safety' followed by returns $(77.5 \%)$, liquidity $(35 \%)$ and tax saving $(22.5 \%)$ and none of the respondents were any others. In case of college teachers $(75 \%)$, decision of investment was influenced by the factor 'safety' followed by returns $(67.5 \%)$, tax saving $(60 \%)$ and liquidity $(52.5 \%)$ respectively.

\section{Introduction}

Savings and investments play a major role in economic development of any country and the primary objective of all government's policy has been to promote savings and capital formation in the economy which is a primary instrument of economic growth. Very few studies have been done on saving and investment behavior of high school and college teachers in Samastipur district of
Bihar. The central concern of this research is not with the process of saving and investment as such, but with broader objectives of understanding saving and investment behavior, major saving and investment avenues, factor affecting saving and investment behavior and constraints faced by the teachers. Thus, the present study was planned with the following specific objective: To identify the factors affecting saving and investment behavior of the respondents. 


\section{Materials and Methods}

\section{Sampling procedure}

A complete list of blocks of Samastipur district was obtained from personal visit to the district, Samastipur. Two blocks from the district were selected purposively. From each block, two high schools and two colleges were selected randomly and from each block, forty teachers (twenty from each high schools and colleges) were selected randomly. Thus, the total number of sample size comprised of eighty high school and college teachers.

\section{Results and Discussion}

\section{Factors affecting saving behaviour}

It was observed that the $85 \%$ of the high school teachers and $80 \%$ of college teachers were highly influenced by income as saving and high school teachers were influenced as education $(77.5 \%)$, wealth $(47.5 \%)$, pension $(32.5 \%)$, stages in life cycle $(30 \%)$, banking infrastructure $(25 \%)$ and employment status (10\%) respectively whereas college teachers were influenced as education (77.5\%), stages in life cycle $(37.5 \%)$, wealth and pension (35\%), banking infrastructure $(27.5 \%)$ and employment status (20\%) respectively.

\section{Factor influence investment decision}

It is observed that the high school respondents $(82.5 \%)$, decision of investment was influenced by the factor 'safety' followed by returns (77.5\%), liquidity (35\%) and tax saving $(22.5 \%)$ and none of the respondents were any others. In case of college teachers (75\%), decision of investment was influenced by the factor 'safety' followed by returns $(67.5 \%)$, tax saving (60\%) and liquidity $(52.5 \%)$ respectively (Table 1$)$.

Table.1 Frequency and percentage distribution of high school and college teachers with factors affecting of saving and investment behavior

\begin{tabular}{|c|c|c|c|c|c|c|}
\hline \multirow[t]{2}{*}{ SI. No. } & \multirow[t]{2}{*}{ Factors } & \multirow[t]{2}{*}{ Categories } & \multicolumn{2}{|c|}{ High school teachers } & \multicolumn{2}{|c|}{ College teachers } \\
\hline & & & $\mathbf{F}$ & $\%$ & $\mathbf{F}$ & $\%$ \\
\hline \multirow[t]{8}{*}{1.} & \multicolumn{6}{|c|}{ Factors affecting saving behaviour } \\
\hline & & Income & 34 & 85 & 32 & 80 \\
\hline & & Education & 31 & 77.5 & 31 & 77.5 \\
\hline & & Wealth & 19 & 47.5 & 14 & 35 \\
\hline & & Employment status & 4 & 10 & 8 & 20 \\
\hline & & Stages in life cycle & 12 & 30 & 15 & 37.5 \\
\hline & & Pension & 13 & 32.5 & 14 & 35 \\
\hline & & Banking infrastructure & 10 & 25 & 11 & 27.5 \\
\hline \multirow[t]{6}{*}{2.} & \multicolumn{6}{|c|}{ Factor influence investment decision } \\
\hline & & Liquidity & 14 & 35 & 21 & 52.5 \\
\hline & & Returns & 31 & 77.5 & 27 & 67.5 \\
\hline & & Safety & 33 & 82.5 & 30 & 75 \\
\hline & & Tax saving & 9 & 22.5 & 24 & 60 \\
\hline & & Any others & 0 & 0 & 0 & 0 \\
\hline
\end{tabular}



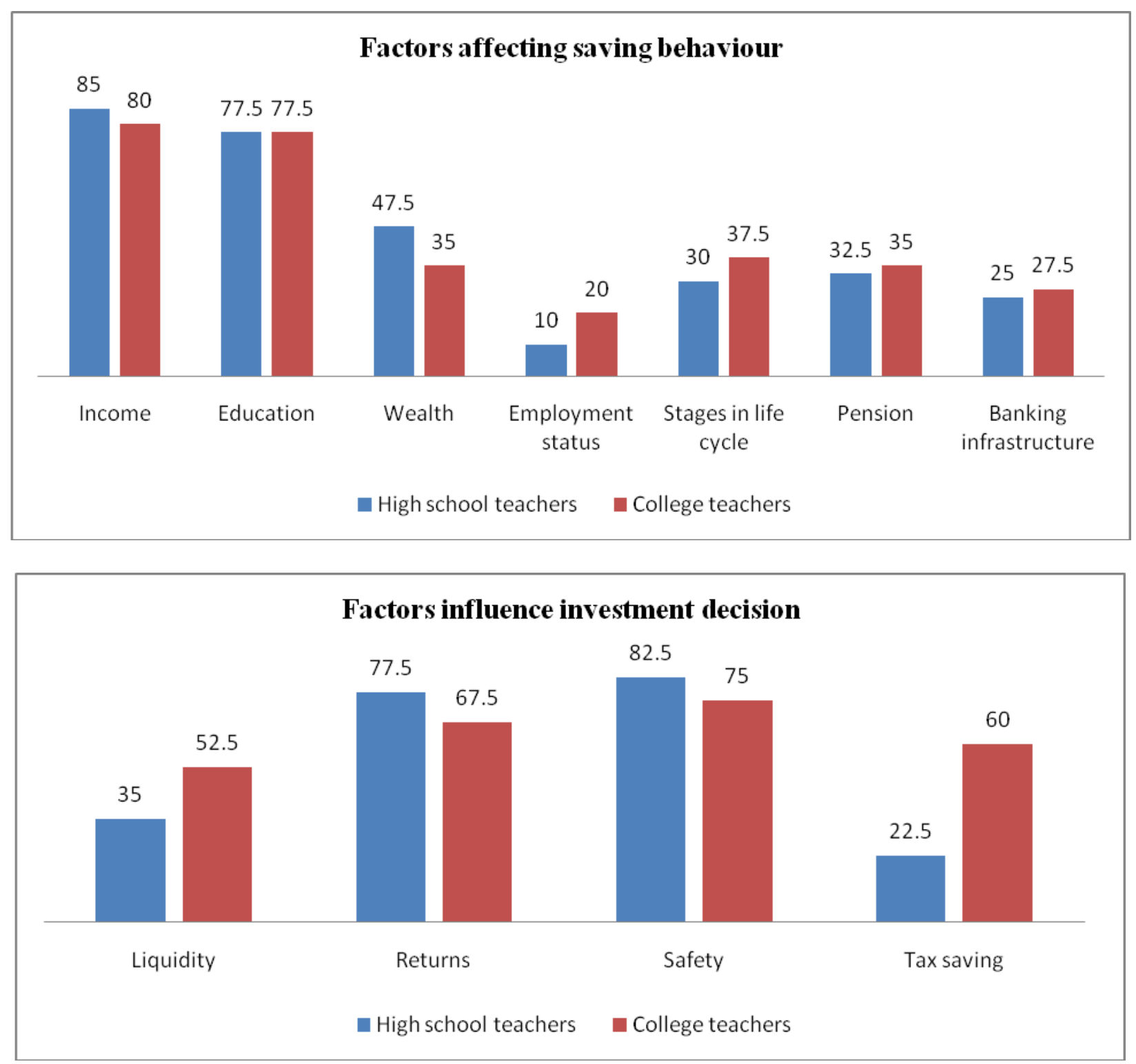

The findings of the study provide relevant information related with selected high school and college teachers of their saving and investment avenues. As per the finding shows that the Eighty five percent of the high school teachers and $80 \%$ of college teachers were highly influenced by their income as saving whereas decision of investment was influenced by the factor safety i.e., $82.5 \%$ (high school teachers) and 75\% (college teachers). Saving and investment can provide the financial protection to the people, at the time of emergency and in order to increase income or production output in the future.

\section{Suggestion for Further Research}

Comparative study on saving and investment behavior of high school and college teachers can be undertaken.

Similar work may be carried out on a large sample.

\section{References}

Achar, A., (2012). Saving and Investment Behaviour of Teachers - An empirical study. International Journal of Physical 
and Social Sciences, August, 2012, pp 263-286.

Agrawal, S., (2010). "Investment Avenues" Disha Institute of Management And Technology, Raipur (www.scribd.com).
Bhardwaj, R., Raheja, R., and Priyanka, (2011). Analysis of Income and Savings Pattern of Government and Private Senior Secondary School Teachers, Asia Pacific Journal of Research in Business Management, 2011, Volume: 2, Issue: 9, pp. 44-56.

\section{How to cite this article:}

Kumari Asmita, Satya Prakash and Kritika. 2018. Factors Affecting Saving and Investment Behavior of the Teachers. Int.J.Curr.Microbiol.App.Sci. 7(06): 278-281. doi: https://doi.org/10.20546/ijcmas.2018.706.032 